\title{
Pengembangan Lembar Kegiatan Siswa Berbasis Penemuan Terbimbing Pada Materi Peluang unTuK SisWa Kelas XI IPA SMA ADABIAH 2 PADANG
}

\author{
DEVELOPING STUDENTS WORKSHEET BASED ON DISCOVERY LEARNING IN \\ Probability Topic for StUdents Science Class XI SMA 2 ${ }^{\text {ND }}$ Adabiah Padang
}

\author{
Sefrida Nengsih ${ }^{1}$, Tika Septia ${ }^{2}$ dan Rina Febriana ${ }^{3}$ \\ 1 Mahasiswa Program Studi Pendidikan Matematika, STKIP PGRI SUMBAR \\ Padang, Sumatera Barat, Indonesia \\ sefridanengsih@gmail.com
}

2,3 Staf Pengajar Program Studi Pendidikan Matematika, STKIP PGRI SUMBAR Padang, Sumatera Barat, Indonesia

\begin{abstract}
Abstrak
Penelitian ini dilatarbelakangi oleh adanya siswa yang belum memahami materi peluang dan penyajian materi pada LKS belum membimbing siswa menemukan konsep secara mandiri. Penelitian ini bertujuan untuk menghasilkan LKS berbasis penemuan terbimbing pada materi peluang untuk siswa kelas XI IPA SMA Adabiah 2 Padang yang valid, praktis dan efektif. Jenis penelitian ini adalah penelitian pengembangan dengan menggunakan model Plomp yang terdiri atas 3 fase yaitu preliminary research, prototyping phase, dan assessment phase. Tahap preliminary research terdiri dari wawancara kepada siswa dan guru, analisis silabus, dan analisis buku teks. Tahap prototyping phase yaitu merancang sistematika dan struktur LKS, penyusunan prototipe, evaluasi diri, tinjauan ahli, evaluasi satu-satu dan evaluasi kelompok kecil. Tahap assessment phase yaitu uji kelompok besar terhadap satu kelas yaitu kelas XI IPA 3 sebagai kelas ekperimen.Hasil penelitian menunjukkan LKS berbasis penemuan terbimbing valid, praktis, dan efektif dalam meningkatkan hasil belajar dan memotivasi siswa.

Kata Kunci: Pengembangan, Lembar Kegiatan Siswa, Penemuan Terbimbing.
\end{abstract}

\begin{abstract}
This research is motivated by the existence of students who do not understand the material opportunities and presentation of the material on the LKS has not lead the students find the concept independently. This study aims to produce LKS based on guided discovery on the material opportunities for students of class XI IPA SMA Adabiah 2 Padang valid, practical and effective. This type of research is a development research using a plomp model consisting of 3 phases, namely preliminary research, prototyping phase, and assessment phase. The preliminary research stage consists of interviews to students and teachers, syllabus analysis, and textbook analysis. Phase prototyping phase is designing LKS systematics and structures, prototype arrangement, self-evaluation, expert review, one-to-one evaluation and small group evaluation. The assessment phase phase is a large group test of one class that is class XI IPA 3 as the experimental class. The result of the research shows that LKS based on the discovery of guidance is valid, practical, and effective in improving learning outcomes and motivating students.
\end{abstract}

Keyword: Development, Student Activity Sheet, Guided Discovery. 


\section{Pendahuluan}

Bahan ajar merupakan seperangkat bahan yang disusun secara sistematis untuk kebutuhan pembelajaran yang bersumber dari bahan cetak, alat bantu visual, audio, video, multimedia, animasi, serta komputer dan jaringan. Bahan ajar sangat berperan dalam mencapai tujuan pembelajaran, memenuhi standar kompetensi, serta dapat memberikan informasi yang cepat bagi siswa. Selain itu, bahan ajar dapat dimanfaatkan untuk memicu pembelajaran yang lebih menarik, siswa lebih mandiri dalam belajar, serta membangun komunikasi yang efektif antara siswa dan guru.

Berdasarkan Observasi yang dilakukan di kelas XI IPA SMA Adabiah 2 Padang, ditemukan kenyataan bahwa dalam proses pembelajaran siswa telah menggunakan LKS, namun penyajian materi pada LKS belum mampu membantu siswa untuk memahami materi. Penyajian materi pada LKS disajikan secara langsung. Materi pada LKS disajikan menggunakan penjelasan yang relatif singkat. Penjelasan tentang materi yang singkat akan berdampak kurang baik terhadap pemahaman konsep siswa.

Hasil wawancara bersama guru diperoleh informasi bahwa materi peluang merupakan salah satu materi yang sulit untuk dimengerti oleh siswa. Guru juga menjelaskan bahwa penyajian materi pada LKS belum mampu membimbing siswa dalam memahami konsep. Hal ini sesuai dengan hasil wawancara dengan beberapa orang siswa, dimana siswa merasa kesulitan dalam memahami konsep secara mandiri karena didalam LKS konsep disajikan secara langsung. Kondisi ini menyebabkan siswa hanya menunggu penjelasan materi secara keseluruhan dari guru. Siswa mengharapkan bahan ajar yang mampu membimbing siswa dalam menemukan konsep serta dapat memotivasi mereka untuk belajar.

Berdasarkan permasalahan yang ada, maka diperlukan suatu bahan ajar yang mampu membimbing siswa dalam menemukan konsep serta memotivasi siswa. Salah satu bahan ajar yang dapat dikembangkan adalah LKS berbasis penemuan terbimbing. Prastowo (2011 : 203) menyatakan bahwa lembar kegiatan siswa (student work sheet) adalah lembaran-lembaran berisi tugas yang harus dikerjakan oleh peserta didik berupa petunjuk atau langkah-langkah untuk menyelesaikan suatu tugas dan tugas tersebut haruslah jelas kompetensi dasar yang akan dicapai. Pembelajaran dengan Lembar Kegiatan Siswa (LKS) memungkinkan siswa belajar lebih cepat menyelesaikan satu kompetensi dasar (KD) atau lebih, karena siswa dapat mempelajarinya terlebih dahulu, dan pada lembar kegiatan siswa (LKS) yang dikembangkan terdapat materi serta kaya akan soal-soal latihan yang akan membimbing siswa dalam menemukan konsep, sehingga LKS yang diberikan bisa mengarahkan siswa untuk dapat menyelesaikan masalah matematika yang berhubungan dengan kehidupan nyata. 
Penelitian ini bertujuan untuk mengembangkan LKS berbasis penemuan terbimbing pada materi peluang yang valid, praktis dan efektif untuk siswa kelas XI IPA SMA Adabiah 2 Padang. Penelitian yang relevan dengan penelitian ini adalah penelitian Pika Purnama Sari (2014) dengan judul "Pengembangan Lembar Kegiatan Siswa Berbasis Penemuan Terbimbing pada Materi Lingkaran Kelas VIII Di SMP Negeri 4 Kota Bengkulu".

\section{Metode}

Jenis penelitian yang dilakukan adalah penelitian dan pengembagan (Research and Development/R\&D). Menurut Sugiyono (2011: 427) "Penelitian dan pengembangan (Research and Development/R\&D) adalah metode penelitian yang digunakan untuk meneliti sehingga menghasilkan produk baru, dan selanjutnya menguji keefektifan produk tersebut". Produk yang dihasilkan dalam penelitian ini adalah alat bantu pembelajaran matematika yang berupa LKS berbasis penemuan terbimbing.

Desain penelitian ini menggunakan model Plomp (2013: 30) yang terdiri atas 3 fase yaitu preliminary research, prototyping phase, dan assessment phase. Tahap preliminary research terdiri dari wawancara kepada siswa dan guru, analisis silabus, dan analisis buku teks. Tahap prototyping phase yaitu merancang sistematika dan struktur LKS, penyusunan prototipe, evaluasi diri, tinjauan ahli, evaluasi satu-satu dan evaluasi kelompok kecil. Tahap assessment phase yaitu uji kelompok besar terhadap satu kelas yaitu kelas XI IPA 3 sebagai kelas ekperimen. Instrumen yang digunakan adalah lembar observasi, angket, pedoman wawancara, soal pretest dan posttest. Data yang diperoleh dianalisis secara kualitatif dan kuantitatif. Teknik analisis data dari angket adalah hasil angket dari guru dan siswa terhadap LKS. Selanjutnya dicari nilai persentase kepraktisan LKS dengan rumus yang dikemukakan oleh Riduwan (2013: 39). Hasil wawancara terhadap siswa dianalisis dengan menggunakan teknik deskriptif yang dikemukakan oleh Miles dan Huberman (1992:16).

Data efektivitas dilakukan dengan menganalisis hasil pretest dan posttest dengan rumus N-Gain yang dikemukakan oleh Richard R. Hake (1999). Hasil angket motivasi belajar siswa dianalisis dan dicari persentase keefektifan dengan rumus yang dikemukakan oleh Riduwan (2012:89).

\section{Hasil dan Pembahasan}

Validitas adalah tingkat keterukuran LKS berdasarkan isi dan konstruk. LKS ini divalidasi oleh dosen matematika STKIP PGRI Sumatera Barat, guru matematika SMA Adabiah 2 Padang, dan guru bahasa Indonesia SMA Adabiah 2 Padang. Data hasil penilaian validator dideskripsikan dan dianalisis secara kualitatif dan kuantitatif. Hasil validasi Lembar Kegiatan Siswa (LKS) berbasis penemuan terbimbing dari ketiga validator dapat dilihat pada tabel 1 berikut. 
Tabel 1.

Hasil validasi seluruh aspek pada LKS

\begin{tabular}{lcc|}
\hline \multicolumn{1}{c}{$\begin{array}{c}\text { Aspek } \\
\text { Validasi }\end{array}$} & $\begin{array}{c}\text { Nilai } \\
\text { Validitas }\end{array}$ & Kategori \\
\hline Kelayakan Isi & $83,33 \%$ & Sangat Valid \\
\hline Penyajian & $84,72 \%$ & Sangat Valid \\
\hline Bahasa & $75,92 \%$ & Valid \\
\hline Kegrafikan & $80,56 \%$ & Sangat Valid \\
\hline $\begin{array}{l}\text { Persentase } \\
\text { keseluruhan }\end{array}$ & $81,13 \%$ & Sangat Valid \\
\hline
\end{tabular}

Berdasarkan persentase keseluruhan yang terdapat pada Tabel 1, dapat disimpulkan bahwa LKS berbasis penemuan terbimbing pada materi peluang berada pada kategori sangat valid. LKS yang telah valid kemudian diuji kepraktisannya dengan melibatkan satu orang guru matematika dan tiga orang siswa pada tahap evaluasi satu-satu. Sedangkan pada tahap evaluasi kelompok kecil melibatkan 6 orang siswa. Siswa yang dipilih pada tahap evaluasi satu-satu dan evaluasi kelompok kecil merupakan siswa yang telah mempelajari materi peluang yaitu kelas XII IPA SMA Adabiah 2 Padang.

Praktikalitas LKS berbasis penemuan terbimbing bertujuan untuk melihat keterpakaian LKS oleh siswa. Tahap praktikalitas dilihat dengan menggunakan angket dan melakukan wawancara dengan beberapa siswa tentang pelaksanaan pembelajaran untuk melihat kemudahan, waktu, mudah diinterpretasikan dan ekivalensi LKS. Praktikalitas pada tahap evaluasi satu-satu guru diminta untuk memahami LKS dan mengisi angket praktikalitas, sedangkan ketiga orang siswa diminta untuk mengisi LKS dan angket praktikalitas serta melakukan wawancara terkait dengan praktikalitas LKS berbasis penemuan terbimbing pada materi peluang.

Setelah evaluasi satu-satu selesai maka dilakukan evaluasi kelompok kecil. Siswa diminta untuk belajar menggunakan LKS dan mengisi angket praktikalitas serta melakukan wawancara tentang praktikalitas LKS. Setelah dilakukan penilaian terhadap hasil kerja siswa pada tahap evaluasi satu-satu dan evaluasi kelompok kecil dalam menyelesaikan soalsoal dalam LKS, dapat disimpulkan bahwa siswa bisa memahami dan mengerti dengan petunjuk-petunjuk yang diberikan dalam LKS dan soal-soal yang diberikan mampu diselesaikan siswa dengan baik meskipun masih terdapat beberapa soal yang kurang tepat dalam menentukan penyelesaiannya serta masih terdapatnya soal-soal yang tidak dijawab oleh siswa. Namun, secara keseluruhan dapat disimpulkan bahwa siswa mampu memahami materi peluang yang diberikan dalam LKS.

Berdasarkan hasil dari angket praktikalitas LKS serta wawancara terhadap guru dan siswa, dapat disimpulkan bahwa LKS berbasis penemuan terbimbing pada materi peluang dikategorikan praktis.

Untuk angket kepraktisan LKS oleh guru dan siswa pada svaluasi satu-satu dan evaluasi kelompok kecil, rata-rata hasil analisis angket praktikalitas guru pada evaluasi satu-satu sebesar 91,67\% dengan kategori sangat praktis dan rata-rata hasil angket praktikalitas siswa pada evaluasi satu-satu sebesar 87,96\% dengan kategori 
sangat praktis. Sedangkan pada evaluasi kelompok kecil rata-rata hasil angket praktikalitas siswa sebesar 87,96 dengan kategori sangat praktis. Hasil angket pratikalitas tersebut menunjukkan bahwa aspek kemudahaan dalam penggunaan LKS berbasis penemuan terbimbing membantu siswa dalam memahami materi, dapat membuat siswa membangun pengetahuanya sendiri, memudahkan guru dalam membimbing siswa menemukan konsep dan petunjuk penggunaan serta materi yang disajikan mudah dipahami, dengan hasil angket praktikalitas aspek kemudahan dalam pengguna oleh guru dan siswa.

Untuk wawancara dengan guru dan siswa pada evaluasi satu-satu dan evaluasi kelompok kecil, hasil wawancara dengan guru dan siswa pada tahap evaluasi satusatu dan evaluasi kelompok kecil dapat disimpulkan bahwa LKS berbasis penemuan terbimbing sudah praktis baik dari segi kemudahan penggunaan LKS, waktu yang diperlukan, mudah diinterpretasikan, dan memiliki ekivalensi yang sama.

Data efektivitas dilihat dari hasil belajar berupa pretest dan posttest. Rata-rata nilai pretest dan posttest dapat dilihat pada tabel 2 berikut.

Tabel 2.

Rata-rata nilai pretest dan posttest

\begin{tabular}{cccc|}
\hline Nilai & Mean & Min & Max \\
\hline Pretest & 42,86 & 8 & 88 \\
\hline Posttest & 83,68 & 65 & 96 \\
\hline
\end{tabular}

Berdasarkan Tabel 2, dapat diketahui bahwa rata-rata nilai pretest dan posttest adalah 42,86 dan 83,68 . Nilai minimum pada saat pretest dan posttest adalah 8 dan 65. Nilai maksimum pada pretest adalah 88 sedangkan pada saat posttest adalah 96. Grafik rata-rata nilai prestest dan posttest dapat dilihat pada Gambar 1.

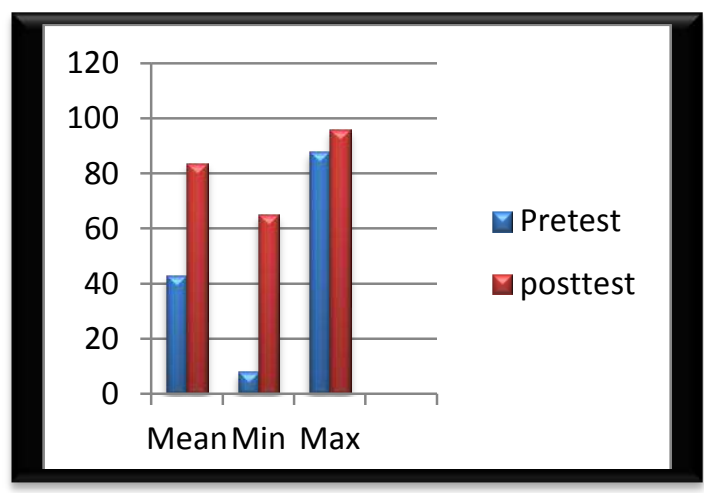

Gambar 1. Contoh Keterangan Gambar [1].

Berdasarkan Gambar 1, dapat dilihat bahwa rata-rata nilai pretest siswa lebih rendah jika dibandingkan dengan rata-rata nilai posttest. Hal ini berarti hasil belajar siswa meningkat.

Efektivitas penggunaan LKS berbasis penemuan terbimbing pada materi peluang dilihat dengan menggunakan perhitungan gain ternormalisasi (N-Gain). Hasil perhitungan gain ternormalisasi diperoleh nilai untuk keefektifan LKS adalah 0,68 dengan ketegori sedang. Keefektifan LKS juga dilihat dari persentase hasil angket motivasi yaitu $81 \%$ dengan kriteria sangat memotivasi. Berdasarkan hasil uji N-Gain dan hasil angket motivasi dapat disimpulkan bahwa LKS berbasis penemuan terbimbing pada materi peluang efektif dalam meningkatkan hasil belajar dan memotivasi siswa. Jadi, hal ini menunjukkan bahwa LKS berbasis 
penemuan terbimbing valid, praktis, dan efektif.

\section{Penutup}

LKS berbasis penemuan terbimbing yang dikembangkan pada materi peluang dilihat dari aspek kelayakan isi, penyajian materi, kebahasaan dan kegrafikan dinyatakan sangat valid dengan persentase nilai kevalidan yaitu $81,13 \%$. LKS berbasis penemuan terbimbing yang dikembangkan pada materi peluang dilihat dari kemudahan penggunaan LKS, waktu yang diperlukan, mudah diinterpretasikan, dan memiliki ekivalensi yang sama sudah sangat praktis digunakan oleh guru dan siswa pada uji praktikalitas evaluasi satusatu dengan persentase nilai yang diberikan oleh guru yaitu 91,67\% dan siswa 87,96\%. Sedangkan uji praktikalitas pada evaluasi kelompok kecil, LKS memperoleh persentase nilai kepraktisan sebesar $87,96 \%$. LKS berbasis penemuan terbimbing yang dikembangkan pada materi peluang telah efektif yang dilihat dari hasil angket motivasi dan hasil belajar siswa dengan menggunakan pretest dan posttest. Persentase hasil angket motivasi belajar siswa yaitu $81 \%$ dengan kategori sangat memotivasi. Rata-rata hasil belajar siswa juga telah meningkat yang dilihat dari hasil uji n-gain yaitu 0,68 dengan kriteria keefektifan sedang.

LKS berbasis penemuan terbimbing yang valid, praktis dan efektif dapat dijadikan sebagai bahan ajar pendamping buku teks pembelajaran matematika pada materi peluang di kelas XI IPA SMA. Selain itu, LKS berbasis penemuan terbimbing dapat dijadikan contoh bagi peneliti lainnya dalam mengembangkan LKS lainnya.

\section{Daftar Pustaka}

Miles, Matthew B \&Huberman, A Michael. (1992). Analisis Data Kualitatif (TjetjepRohendiRohidi.Terjemahan). Jakarta: Universitas Indonesia

Purnama Sari Pika. (2014)." Pengembangan Lembar Kerja Siswa Berbasis Penemuan Terbimbing Pada Materi Lingkaran Kelas VII di SMP Negeri 4 Kota Bengkulu". Skripsi. Universitas Bengkulu.

Plomp, T \& Nienke Nieveen. 2013. Educational Design Research Part A: An Introduction. Enschede: slo

Prastowo, Andi. 2011. Panduan Kreatif Membuat Bahan Ajar Inovatif. Jogjakarta: Diva Press.

Riduwan. 2005. Belajar Mudah Penelitian untuk Guru, Karyawan dan Penulis Pemula. Bandung : Alfabeta.

Riduwan. 2013. Dasar-dasar Statistika. Bandung: Alfabeta.

Riduwan. 2013. Skala Pengukuran Variabel-variabel Penelitian. Bandung: Alfabeta. 